現はれる。Zirkite 單味では煉瓦に成形することは困 難であるが少量の粘土を加へると $2300^{\circ} \mathrm{C}$ の高盜度に 涌える耐火榻酉を作ることが出來る。茂木

郎火材料（米特許，2021222,1935）此の耐火材料 は $48 \% \mathrm{MgO} 42 \% \mathrm{SiO}_{2}$ 及 $2 \sim 20 \% \mathrm{FeO}$ を含むオリ ビンの 5〜15 分と, $\mathrm{FeO}, \mathrm{Cr}_{2} \mathrm{O}_{3}$ を含むクロマイトの 5〜15 分及 $\mathrm{CaO}, \mathrm{MgO}$ を含む煆燒ドロマイトの 5〜15 分から作つた渜火物である。茂木

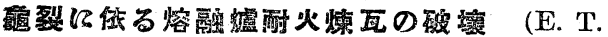

Richards, Feuerungstech. 1935, 23, 49〜52) 㯖瓦の 破瑞は熱及機棫的の原因，或は煉瓦の構造の戀化に依 つて起る。鵤裂は主として溫度の急變に依る。煉瓦の

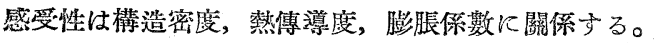
踏瓦に彈力性があり，多孔性（或極限までの）がある 程, 溫度の急變に强い。棈造け使用中の溫度及化學作 用のために變化を起し, 此の變化は煉瓦の加熱部から

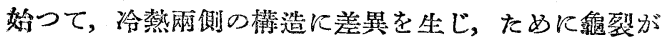
起るのである。 茂 林

\section{V. 建築用品}

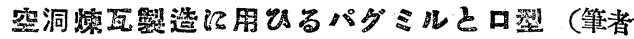
不棓, The Brit. Clayworker, 1936, 44 [525], 299

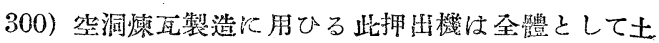
絬空とオーヂャーとに分離され，練つた土は其下のオ ーヂャーの胴に抽迟れる。父口型の前にはコンベーャ 一があつて一旦押出された土住此コンべーヤーに依つ て亞び土練宝に運げれる樣にして，斯くする閒に土の 水分は 26\%から $24 \%$ に減ぜられる。茲では胴と口.

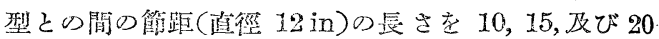
in に變化して行つて, 口型の働きに對する節距の長

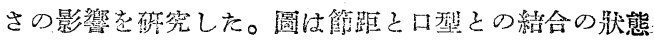
を示すものでらる。

又口型は其傾斜を $0,2,3,4$ 及び $6^{\circ}$ 亿變化し且此傾 斜は口型の最初の $3^{\prime \prime}$ に限定した。郎亏 4 " の口型な らば俔斜した部分の長主 $3^{\prime \prime}$, 平部の部分 $1^{\prime \prime}, 6^{\prime \prime}$ の口

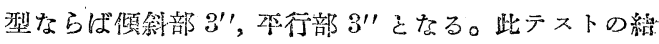

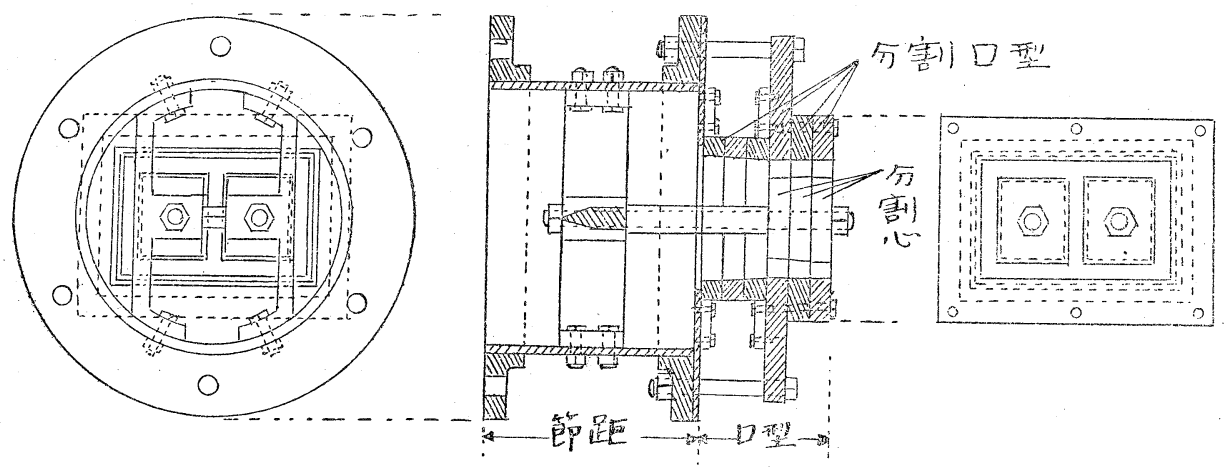

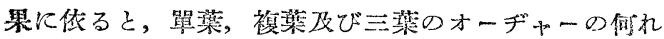
の場合を問はず，艮さ $10^{\prime \prime}$ の節距，30の傾斜の $4^{\prime \prime}$

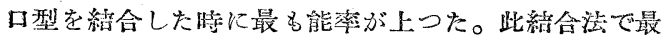
大押出速度を分賞り，一馬力當りで求めたが，挴出迹 度及び動力費に關して纺單琵式は最も能率奵く，三菜 式は複葉式より良加つた。文單菜螺旋を用ひ，5－6" の口型を用ひた時に最も满足な粘土杜が得られ， $4^{\prime \prime}$ の口型では不㵀足であつた。節距は長い程動力量を高 める結哭となつた。口棐の長され押出速度には影響な 、が，動力量に對をる影響は大なる名のがあつた。傾

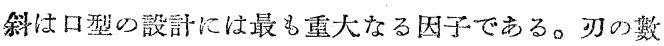

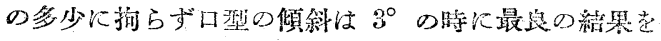
得た。

\section{肉田}

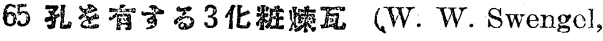
Brick Clay Rec., 1985, 87 [5], 154) Teh Royalton

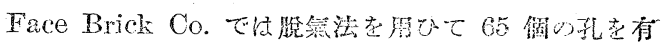

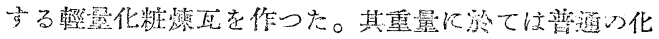

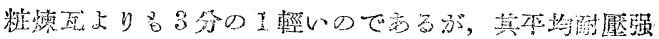

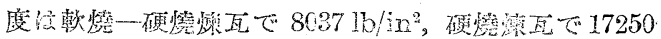
$\mathrm{lb} / \mathrm{in}^{2}$ ねしてみる。

附田

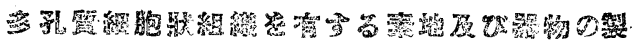
活(Gustav Acioiph \& Theocor Pohl. U. S. 2024791,

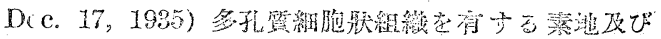

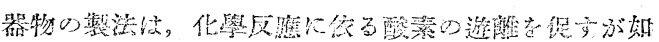

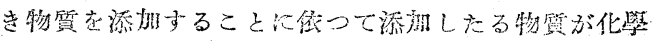

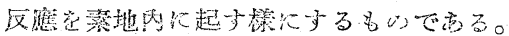

$$
\text { 防田 }
$$

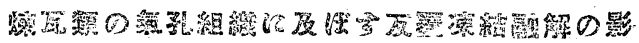

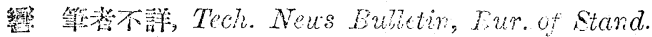

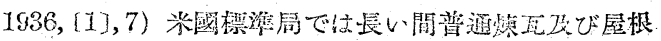


瓦の耐水性の決定法の樹立に從事してるる。新しい研 究に依つて凍結及び融解が買瓦類の氣孔組織に對して 如何なる影響を與一るかを決定しなければならない。 實驗法: 惯驗次の如く行つた。䬦ち, 煉瓦は 48 時 間凍結したる後水中で融解し， $110^{\circ} \mathrm{C}$ で乾燥して, 乾 燥重量, 全容積, 固體の部分の容積, 氣孔率, 密度, 吸水率及び通氣率を測定した。通氣率に對して見出さ れを值は，学氣の透過は毛管度 (Kapillarität) の法則 (Fachschr. Tonind. Zeit. 1936。[4]) に從ふととを 示すから, 烑瓦試料は各實驗の進行に從つて氣孔の本 均牛徑及び其數をポアジュイール (Poisseuille) の式 に從つて訪算した。實驗結果：(1) 整瓦の全容積及び 吸水率江事實上變化を受けてるない，(2）固體の部分 の容積，逝氯率及び毛管の本均直徑は上述の要求に依 つて大となつてるる，(3) 密度, 氣孔率及び毛管の數 は隇少してるる。

内。田

营の炻器と今日の炻器 (Felix Singer, Ceram Age, 1936, 27 [2], 7 9) 今日の化學用炻器は完全に 磁器化し, 白色又は有色の不透明素地で, 又其化學組 成は廣い範圍で變化してるる。郎ち，適當に作られた る炻器素地では, 不燃質にして, $1400^{\circ} \mathrm{C} て ゙$ 分解されず 蒸發せず還元せられざる凡ての物質が多少に拘らず 添加され, 斯くして炻器の物理的性質は非常に廣い籁 图で調節乃至變更されるのである。今日の炻器と一昔 前の夫の物理的性質を對比すると次の如くである。 節ち,

\begin{tabular}{|c|c|c|}
\hline & 1921 & 1933 \\
\hline 耐厴强度 $\left(\mathrm{lb} / \mathrm{in}^{2}\right)$ & 82721 & 116771 \\
\hline 耐伸强度 $\left(\mathrm{lb} / \mathrm{in}^{2}\right)$ & 1650 & 7510 \\
\hline 屈曲抵抗 $\left(\mathrm{lb} / \mathrm{in}^{2}\right)$ & 5917 & 13555 \\
\hline 彈性係數 (lb/in²) & $5.95 \times 10^{-6}$ & $5.95 \times 10^{-6}$ \\
\hline 研磨試驗（損失 $/ \mathrm{in}^{3}$ ) & 0.183 & 0.037 \\
\hline 掭抵抗 $\left(1 b / \mathrm{in}^{2}\right)$ & 3570 & 4595 \\
\hline 吸水率 $(\%)$ & 0.5 & 0 \\
\hline 膨脹係數 (1 ${ }^{\circ} \mathbf{F}$ r付) & $2.3 \times 10^{-6}$ & $0.083 \times 10^{-6}$ \\
\hline 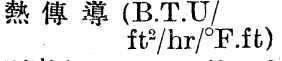 & 0.9 & 2.65 \\
\hline $\begin{array}{c}\text { 硬度(ブリネルに等しきき } \\
\text { ボール壓カテスト) }\end{array}$ & 1044 & 1253 \\
\hline 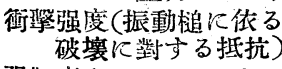 & 1.9 & 4.97 \\
\hline $\begin{array}{c}\text { 强勒度(ボールミル中に } \\
\text { 於ける重量損失) }\end{array}$ & 3.6 & 2.6 \\
\hline
\end{tabular}

今日に泛ける炻器の用途を觀ると, 硫酸, 監酸及び确 㖫工業に於ける冷却及び洗滌塔, 吸收及び反應塔, 其 充塓物，液の分布機。薿縮酒，コイルでは其化學的及 び機械的抵抗性の外に急速なる熱傳達なる特殊條件を
滿足するものでなりればならぬ。活潑なる瓦斯及び液 體の運搬及び混合にはインヂェクター,エレベーター, エマルザー，酸卵（水蒸氣文は壓縮空氣の作用を受け る)、エクゾースター，遠心ポンプ及びフォースポンプ が必要である。是等の棈造上の完全を確保する篇には 材料の機械的性質の特に精密なる知識を晸する。鍋, 桶, タンク, 瓶, 攪拌器及び凡ての種類の化學苝品の 浑搬用容器等の如き空洞容器は其使用目的火從つて種 ふの形狀に製せられ，數百ガロンの容量を持つワンピ ースで製出される。コック，バルブ，絞奔及びフレン デ及び他の接目等の調節器けデザイン上の非常なる精 密度を要求する。炻器》密度は或る場合には甚だ重琵 であるが，又或る場合には硬度及び强靱度が大に要求 されるとと乳鉢，ボールミル等に見るが如くである。 硬度, 强度, 密度及び化學抵抗は齐種のローラーの製 作に重㢺で，例一ば, 計器工業, 漂白工場, 寫寊用紙 の製造に於计る被覆口ール，油繪具製造に拎ける粉碎 ロール, 特に食糧品工栄に於ける粉碎ロール及び均質 にする暇のロール等がある。

龽瓦の着色（Wm. S. Damhorst, U.S. 2020137， Nov. 5，1935）煉瓦成形型（軟土法に依る煉瓦製造に 用ひる砂型法に關聯して用ひる様な）の中等を，細 砂，耐火粘土粉末，着色材料 (“Mn” “金屬赤” 又住 㸮末亞鉛) の混合物を以て被覆（混合物の枌末を乾燥 狀態で涂れる型の壁に施すして後粘土を型に强厴の 下に押达むものである。

內 田

タイルの庙色裝置 (H. F. Wood \& Wm. Coulter, B. P. 432193, July 18, 1935) 一種又は數種の䪿 料を入れた容器の下に, タイルを載せたコンべーヤー を運搬し, 其容器に㢈る數多の質出孔に依つて少量の 顏料をタイルの面にかけるのであるが，顏料はかける 前に別のノズルからの坒䓙のブラストに依つて一面に 撗げられる栐になる。又各種の顏料を混合してタィル の依面にかける栐にするのである。

內 田

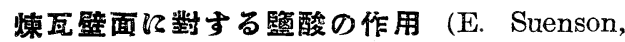
Ingeniorvidenskabelige Skrifter, 1935, A.Nr. 40) 煉瓦壁面及目地が崩燷した現象に就き研究したもので 實驗に基き次の樣に其の機檏を詆明して居る。目地を 塗る前の酸洗（監酸使用）により燌瓦表面及び內部に $\mathrm{CaCl}_{2}$ が生成し之が目地內に過剩の $\mathrm{HCl}$ と共に吸收 され目地內に於て“カル”即ち $3 \mathrm{CaO}, \mathrm{CaCl}, 16 \mathrm{H}_{2} \mathrm{O}$ が晶出する。此の結晶の生長によりモルタルが目地か ら押出され煉瓦とモルタルの附着力が大きい場合煉瓦 が薄片になつて㩆脫するもつである。煉瓦の燒成不足 


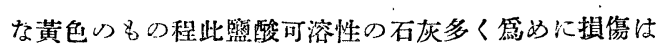
著しい。石庅モルタル，セメントモルタル，石灰セメ ントモルタル何れる损笏されるが後者を用ひた場合最 落しい。

古薮

\section{VI. 硝子及珐瑯}

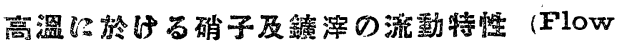

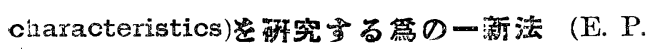

Barrett \& J. A. Tay'er, J. Amer. Cer. Soc., 1936,

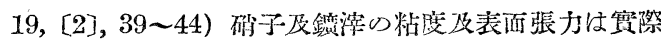
上非常江荲翼な性質であるが之等の性質法屡了測定が 困難でする。結果を絕對つ翌位で出す樣な方法は時間 を食ふし又一部分失透した珪酸監熔融物の性情を研究

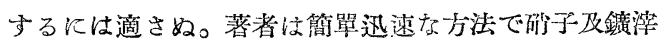
の流動特性を知らルとし次の如き方法を述へて居る。 試驗物質を完全に熔融せしぬ熔融物よりの瓦斯逸出の 止む迄此の温度汇保つた後之を徑 $1 / 2$ 时高さ約 $1 / 2$ 版 つ小體て鑄造する。之を耐火物基底の上飞立て之を特 殊の設計的瓦斯マッフル嘘內に置く。カセトメーター を以て試驗體の高さを测定しつつ $15^{\circ} \mathrm{F} / \mathrm{min}$ の割合で 溫度を上昇せしめ試驗體が㐬九て最初の高さの $20 \%$ になるに至つて止む。溫度子試驗體の高さ（最初の高 さと對する\%を以て表はす）明線沉描き之を以て特

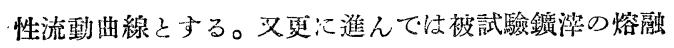
途上にある塊の基底（例・ばアームコ践の如き物の基

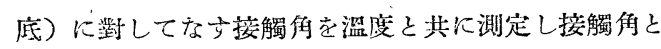
溫度とを曲線に描く。之等の曲線より試驗物質の㮔々

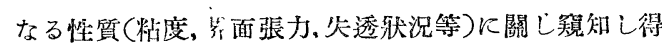
るところが大である。此の方法は非常に咸筑圊つ組成

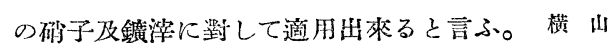

珐瑯の不透明度に及す粘土の裝響 (R.R. Danielson, J. Amer. Cer. Soc., 1936, 19, [2], 59 61) 8 種類の粘土を標準白色フリットに混じ之を上掛に用 ひて其の結果をッアイスの反射計 (reflectometer) で 檢し reflectance を測るに粘土に依り異り最大 $5 \%$ の 差があつた。此の $5 \%$ と言ふ差は大きなものなのであ る。最大の不透明度を與一る粘土注正常最良の罌濁を

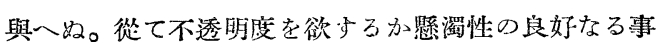
を欲するか場合て上り使用粘土儿就导考慮選擇せねば なら收。良好な賄濁性を持て居る粘土と高い不透明度 を與一る粘土と 2 種の粘土を混じて用ひると言ふ事も 一手段である。賽驗によれば斯る方法沉依り所期の效 果を擧げ得た。

蓝 山

硝子の雪力の解除 (H. R. Lillie, J. Amer.Cer.
Soc., 1936, 19, [2]，45－54) 著者は Adams 及 Williamson の徐冷の法䴗飞就き論じ此の法則に就いては 或る根本的な巽傤のある事を述べて居る。かかる異議

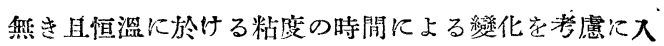
れた新い式， $-d f / d t=M f f \rho$ ，を提出して居る。但し $f$ は歪力, $t$ は時問, $\varphi$ は流動度 (fluidity), M はモ ブュラス (modulus) のダイメンション (dimension) を持つ恒數である。通常の石灰确子江就いての筫騟つ 絬果此の法則は歪の無い矿子に課せられた機械的歪力 の解除にも亦急冾された試驗體に於ける攀的歪力の解 除にも適用される事を知つた。主等 2 種の型の歪力に

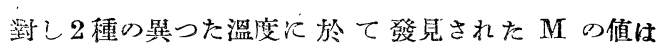
$5.9( \pm 0.5) \times 10^{10} \mathrm{dynes} / \mathrm{cm}^{2}$ であうた。满山

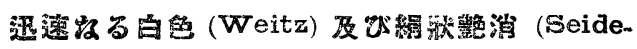
nmatt) 法 (E. Arnot, Sprechsaal, 1936, 69, [6], 75７6）化學的櫘滑を迅速に行ふ方法を操作の詳細に 瓦つて述べて居る。弗酸 2 に弗化アンモン 4 を加一 て暖所飞置き溶解せ之めて粗亞廊布にて滤し之次結晶 曹達 1 を少量づつ何间か儿分けて加一る。之が腐蝕液 である。确子器は微酸性にした蒸溜水で洗つて用ひ る。鉜子で碚子器を保持し㦄蝕溶に浸し 2 3 度動か し後机上に置く。2 3 分にして叟消は完成する。後 器物を冷水を以て濯卆湯の中で刷毛之存片で良く洗ひ 最後汇湯で濯ぐ。以上が極めて大體の操作である。中

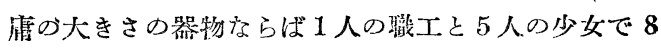
時間に 2000 2400 は出來ると言ふ。曹澾の量に依り

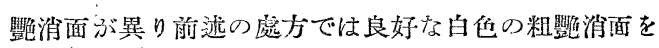
得るが白ざを娍じキメを細かにし所謂絹漛光澤を得る には曹達を減ずればよい。腐融浴の温度はあまり低く てはいけない。倚器物の外側だけ雇领する場合, 內側 だけ腐䭒する場合等に就き其の操作及腐蝕液の處方に 加ふべき修整を述へてて居る。

硝子電極の竌裂唱への應用 (L. R. Parks \& C. R. Barnes, Ind. Eng. Chem., Anat. Ed., 1935, $7,[1], 71 \sim 72)$ 牛乳及其の製品の $\mathrm{pH}$ を測るには普 通水素電極，キンヒドロン電極を腈ひるか此色法に依 るのであるが, 著者治㗂子電極及アンチモン電極をミ ルク, クリーム, バター其他に隹用して見て其の結果 を水素電極及キンヒドロン電極を用ひた結梁と此較し

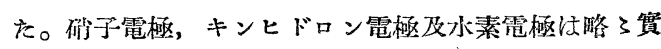
驗誤差の籍薯內に於て一致した結果を與一るがアンチ モン電極の場合は $\mathrm{pH}$ が高く出た。之はアンチモン電 極面に於て学酸監等との閔に錯化合物の生成が起るた めであららと思は执る。 横 


\section{VII. セメント類}

セメント工學行隼用せる $\quad \mathrm{CaO}-\mathrm{Al}_{2} \mathrm{O}_{3}-\mathrm{SiO}_{2}$ $\mathrm{Fe}_{2} \mathrm{O}_{3}$ 柔の相間平衡の研究(I) (F. M. Lea. Zement, 1936, 25 47.)

$\mathrm{CaO}-\mathrm{Al}_{2} \mathrm{O}_{3}-\mathrm{SiO}_{2}, \mathrm{CaO}-\mathrm{Al}_{2} \mathrm{O}_{3}-\mathrm{Fe}_{2} \mathrm{O}_{3}$ 及び $\mathrm{CaO}$

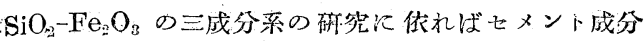
Kは $3 \mathrm{CaO}, \mathrm{SiO}_{2}, 2 \mathrm{CaO}, \mathrm{SiO}_{2}, 3 \mathrm{CaO}, \mathrm{Al}_{2} \mathrm{O}_{3}$ 及で $4 \mathrm{CaO}$, $\mathrm{Al}_{2} \mathrm{O}_{3}, \mathrm{Fe}_{2} \mathrm{O}_{3}$ があり, 其の外飞遫離石灰及び $5 \mathrm{CaO}$, $3 \mathrm{Al}_{2} \mathrm{O}_{3}$ が出來得る。しかし作ら $\mathrm{CaO}-\mathrm{Al}_{2} \mathrm{O}_{3}-\mathrm{SiO}_{2}-$ $\mathrm{Fe}_{2} \mathrm{O}_{3}$ の四成分系こそ最も重琵なものである。

$\mathrm{CaO}-\mathrm{Al}_{2} \mathrm{O}_{3}-\mathrm{SiO}_{2}-\mathrm{Fe}_{2} \mathrm{O}_{3}$ の四成分系の币には $\mathrm{CaO}$ $2 \mathrm{CaO} \cdot \mathrm{SiO}_{2}-5 \mathrm{CaO} \cdot 3 \mathrm{Al}_{2} \mathrm{O}_{3}-4 \mathrm{CaOAl}_{2} \mathrm{O}_{3} \mathrm{Fe}_{2} \mathrm{O}_{3}$ の小さい 四成分系がある。乙れはセメントの抾成の際に出來る 全部の固相液相の化合物を含み一つの獨立した完全な 4 成分系之兒做与事が出來る。即ち夫々 $4 \mathrm{CaO}, \mathrm{Al}_{2} \mathrm{O}_{3}$,

- $\mathrm{Fe}_{2} \mathrm{O}_{3}, 2 \mathrm{CaO} \cdot \mathrm{SiO}_{2}, 5 \mathrm{CaO}, 3 \mathrm{Al}_{2} \mathrm{O}_{3}, \mathrm{CaO}$ 正四面體の頂 點とした平衡圖となる。正四面體を權成する面 $\mathrm{CaO}$ $2 \mathrm{CaO}, \mathrm{SiO}_{-}-5 \mathrm{CaO}, 3 \mathrm{Al}_{2} \mathrm{O}_{3}$ は践の無い場合であり, $\mathrm{Ca}$ O-2 $\mathrm{CaO}, \mathrm{SiO}_{2}-4 \mathrm{CaO}, \mathrm{Al}_{4} \mathrm{O}_{3} \mathrm{Fe}_{2} \mathrm{O}_{3}$ の面估 $\mathrm{Al}_{2} \mathrm{O}_{3}: \mathrm{Fe}_{2} \mathrm{O}_{3}$ の重量比が 0.64 となる時の本衡圖である。しかしい゚ ルトランドセメントは此の中間に位する。上の四成分 柔に現れる化合物は隣の三成分系飞出來る化合物子同 じで新しい三成分义は四成分の化合物は出來ない。結 局三成分系の研究よりセメント中の $\mathrm{CaO}, \mathrm{Al}_{2} \mathrm{O}_{3}, \mathrm{SiO}_{2}$ 及び $\mathrm{Fe}_{2} \mathrm{O}_{3}$ を出す事が出來るがポルトランドセメント には苦土，アルカリ，チタンが少量ある故完全には適 用しない。

ボーグはセメシト币の化合物の䚺算式を與いたが， 夫れにはセメントは燒成温度で殆んど本衡汇達し, 其

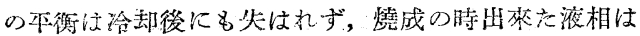
完全汇結晶してるるとの假定がある。

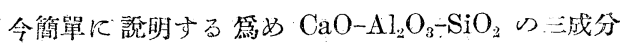

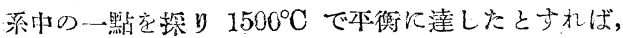
原料よりも石灰含有量多了 $3 \mathrm{CaO}, \mathrm{SiO}_{2}, 2 \mathrm{CaO}, \mathrm{SiO}_{2}$ 江 忙 $\mathrm{CaO}$ を含学固相之，原料上引石灰念有量少く， $2 \mathrm{CaO}_{\mathrm{O}} \mathrm{SiO}_{2}, 3 \mathrm{CaO}, \mathrm{Al}_{2} \mathrm{O}_{3}, 5 \mathrm{CaO}, 3 \mathrm{Al}_{2} \mathrm{O}_{3}$ を含む液相と に分れる。故飞冷却中も本衡交維持するとすれば液相 は $3 \mathrm{CaO}, \mathrm{SiO}_{2}$ を溶解し， $2 \mathrm{CaO}, \mathrm{SiO}_{2}$ 赽晶出しなけれ

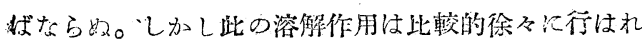
ポルトランドセメントクリンカーは㶼成溫度で液相及 び固相であつ岀ものが目立つ程作用せずして其睢固化 ナる。そして液相は碚子となる事名的るし，一部又は 全部が結晶する蓸もある。次に $\mathrm{CaO}-2 \mathrm{CaO}, \mathrm{SiO}_{2}-4 \mathrm{Ca}$
$\mathrm{O}, \mathrm{Al}_{2} \mathrm{O}_{3}, \mathrm{Fe}_{2} \mathrm{O}_{3}$ 系に於ては燒成溫度で固相は $3 \mathrm{CaO}$ $\mathrm{SiO}_{2}$ と $2 \mathrm{CaOSiO}_{2}$ 苍合み原料上りる石灰含有量少く, 液相は原料よりも石灰含有量が多い。故に液相が続晶 して $3 \mathrm{CaO}, \mathrm{SiO}_{2}$ と $4 \mathrm{CaO}, \mathrm{Al}_{2} \mathrm{O}_{3}, \mathrm{Fe}_{2} \mathrm{O}_{3}$ を作る篇め には遊離石灰を山さなければなら奴。ポル!ランドセ メントは此の二つの極端充例の中間にある。

$\mathrm{CaO}, \mathrm{Al}_{2} \mathrm{O}_{3}, \mathrm{SiO}_{2}$ 及び $\mathrm{Fe}_{2} \mathrm{O}_{3}$ の混合物で $\mathrm{Al}_{2} \mathrm{O}_{3}$ : $\mathrm{Fe}_{2} \mathrm{O}_{3}$ の種々の值に對する燒成物の化合物の計算は四 成分系 $\mathrm{CaO}-2 \mathrm{CaO} \cdot \mathrm{SiO}_{2}-5 \mathrm{CaO} \cdot 3 \mathrm{Al}_{2} \mathrm{O}_{3}-4 \mathrm{CaO} \cdot \mathrm{Al}_{2} \mathrm{O}_{3}$. $\mathrm{Fe}_{2} \mathrm{O}_{3}$ 上り竴く事が出棑るが, 液相がどれでけ結晶し， ぞれだけ确子となるか结泠却方法浽關倸し測定方法は 無い。

村上

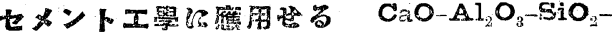
$\mathrm{Fe}_{2} \mathrm{O}_{3}$ 系の相間平畠の醉究 (II) (F. M. Lea. Zement, 1936, 25, 62.)

前祣炕, $\mathrm{CaO}, \mathrm{Al}_{2} \mathrm{O}_{3}, \mathrm{SiO}_{2}, \mathrm{Fe}_{2} \mathrm{O}_{3}$ の混合物の燒成 の際に出來る液相の量江 $\mathrm{CaO}-2 \mathrm{CaO}_{3}, \mathrm{SiO}_{2}-5 \mathrm{CaO}, 3$ $\mathrm{Al}_{2} \mathrm{O}_{3},-4 \mathrm{CaO} \cdot \mathrm{Al}_{2} \mathrm{O}_{3} \cdot \mathrm{Fe}_{2} \mathrm{O}_{3}$ の四成分系上り㵋得る 事を述べが面に 2,3の值を用ひて他の微量成分を含

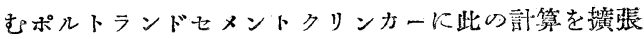
する事が出相る。

セメントの憢成の際汇出來る液相は固相粒于の間を

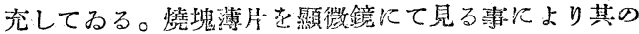
液相部分の量を筫湘する票が出來る。一方 $\mathrm{CaO}, \mathrm{Al}_{2}$ $\mathrm{O}_{3}, \mathrm{SiO}_{2}$ 及飞び $\mathrm{Fe}_{2} \mathrm{O}_{3}$ の混合物を檢查し其の液相部分 を計算する事が出來る。賽測值住良く筧けたクリンカ

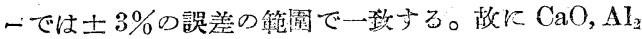
$\mathrm{O}_{3}, \mathrm{SiO}_{2}, \mathrm{Fe}_{2} \mathrm{O}_{3}$ の四成分柔心少量の苦上，アルカッ を加一を時の液相の塯加を顯微镜にて賽測する事が出 來る。 $1375^{\circ} \mathrm{C}$ で液相部分を暂す力は苦士とアルカッ と同じであり，苦土とアルカリ凤合量 $3 \%$ の添加は液 相の量を 4 成分のみの時の倍にする。實際に市販セ メントの苦土とアルカリの合量は $2-5 \%$ であるが夜相 の量も $15-30 \%$ である $\mathrm{CaO}-2 \mathrm{CaO} \cdot \mathrm{SiO}_{2}-5 \mathrm{CaO} \cdot 3 \mathrm{Al}_{2}$ $\mathrm{O}_{3}-4 \mathrm{CaO} \cdot \mathrm{Al}_{2} \mathrm{O}_{3} \cdot \mathrm{Fe}_{2} \mathrm{O}_{3}$ ○ 4 成分系の研究と, 苫士及

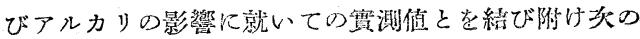
式を得る。

$1340^{\circ} \mathrm{C}$ に政ける液相の量 $(\%)=6.1 \mathrm{y}+\mathrm{a}+\mathrm{b}$

$\begin{aligned} 1400 " \text { " " } & =2.95 \mathrm{x}+2.2 \mathrm{y}+\mathrm{a}+\mathrm{b} \\ 1450 " \text { " } & =3.0 \mathrm{x}+2.25 \mathrm{y}+\mathrm{a}+\mathrm{b}\end{aligned}$

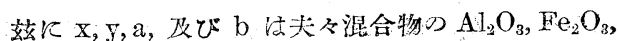
$\mathrm{MgO}$ 及খ゙アルカリの量である。液相の量は石灰と㫜

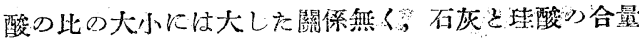
に關㐿する。 $1400^{\circ} \mathrm{C}$ で燒成したセメント 150 稙に就 
いて計算すると液相の量は，白色ポルトランドセメン トでは 15〜22\%，普通ポルトランドセメントでは 17 〜35\%である。よく燒けたクリンカーでは 25〜50\% の液相を合むものが小數あつた。

$\mathrm{Al}_{2} \mathrm{O}_{3}, \mathrm{Fe}_{2} \mathrm{O}_{3}$ が小量であれば液相の量㫐少い, 1400 ${ }^{\circ} \mathrm{C}$ で液相の量を $22 \%$ 以下とし，しかも遊離石灰を微 量にするのは困難であり，白色セメントに比較的遊離 石灰の多いのは其の䉆めである。 $\mathrm{Al}_{2} \mathrm{O}_{3}, \mathrm{Fe}_{2} \mathrm{O}_{3}$ を多く すれば $1338^{\circ} \mathrm{C}$ に於ても多量の液相を生じる。

村上

$1300^{\circ} \mathrm{C}$ 绝於ける3CaO. $\mathrm{SiO}_{2}$ の生成熱 $(\mathrm{H} . \mathrm{Elo}-$ ner. V. Gronow. Zement, 1936, 25, 61,)

多くの研究の結果に依れば $3 \mathrm{CaO} . \mathrm{SiO}_{2}$ の生减には 嚾少の賽熱量を件ふに過ぎない。 $3 \mathrm{CaO} . \mathrm{SiO}_{2}$ はしば しば $2 \mathrm{CaO} . \mathrm{SiO}_{2}$ に $\mathrm{CaO}$ が固溶體となつてみるかの 䈋である。

$3 \mathrm{CaO} . \mathrm{SiO}_{2}$ の生成は僅かに吸熱反憵であり,高溫汅 於ては零に近づく，計算には次の數值を用ひる。

溶俳熱の差より求めた $20^{\circ} \mathrm{C}$ に於ける $3 \mathrm{CaO} . \mathrm{SiO}_{2}$ の生成熱。 $-0.47 \mathrm{cai} / \mathrm{mol}=-2.06 \mathrm{cal} / \mathrm{g}$

$\mathrm{CaO}$ の比熱 $\left(20-1 \subseteq 00^{\circ} \mathrm{C}\right)$ $15.58 \mathrm{cal} / \mathrm{mol}$ $3 \mathrm{CaO} . \mathrm{SiO}_{2}$ の比熹 $\left(20-1500^{\circ} \mathrm{C}\right)$ $71.25 \mathrm{cal} / \mathrm{mol}$ $\beta-2 \mathrm{CaO} . \mathrm{SiO}_{2}$ の比熱 $\left(20-13 \mathrm{CO} 0^{\circ} \mathrm{C}\right) \quad 56.01 \mathrm{cal} / \mathrm{mol}$ $3 \mathrm{CaO} . \mathrm{SiO}_{2}$ の水和熱 $\left(20^{\circ} \mathrm{C}\right) 27.4 \mathrm{cal} / \mathrm{mol}=120 \mathrm{cal} / \mathrm{g}$ $\boldsymbol{\beta}-2 \mathrm{CaO} . \mathrm{SiO}_{2}$ の水和熱 $\left(20^{\circ} \mathrm{C}\right)$ $10.7 \mathrm{cal} / \mathrm{mol}$ $=62 \mathrm{cal} / \mathrm{g}$

$\mathrm{CaO}$ の水和熱 $\left(20^{\circ} \mathrm{C}\right) \quad 15.64 \mathrm{cal} / \mathrm{mol}=279 \mathrm{cal} / \mathrm{g}$

(1) $1300^{\circ} \mathrm{C}$ に於ける $3 \mathrm{CaO} . \mathrm{SiO}_{2}$ の生成熹は $20^{\circ} \mathrm{C}$ に於ける $3 \mathrm{CaO} . \mathrm{SiO}_{2}$ の生成熱と表に與一た $2 \mathrm{CaO}$. $\mathrm{SiO}_{2}$ ๖ $\mathrm{CuO}$ の比熱より

$1300^{\circ} \mathrm{C}$ に於ける $3 \mathrm{CaO} . \mathrm{SiO}_{2}$ の生成熱

$$
\begin{aligned}
& =-0.47+71.25-56.01-15.58 \\
& =-0.13 \mathrm{cal} / \mathrm{mol}=-2.06 \mathrm{cal} / \mathrm{g}
\end{aligned}
$$

(2) $20^{\circ} \mathrm{C}$ K於て $1 \mathrm{~mol}$ の $3 \mathrm{CaO} . \mathrm{SiO}_{2}$ の水和熱は $27.4 \mathrm{cal}$ であり, $\beta-2 \mathrm{CaO} . \mathrm{SiO}_{2}$ は $10.7 \mathrm{cal}$ である, 故 K $2 \mathrm{CaO}, \mathrm{SiO}_{2}+\mathrm{CaO} \longrightarrow 3 \mathrm{CaO} . \mathrm{SiO}_{2}$ が賽熱量零なれ ば $\mathrm{CaO}$ の水和爇は 27.4-10.7=16.7 cal $/ \mathrm{mol}$ そなるい きである。然るに $\mathrm{CaO}$ の水和熱は $15.64 \mathrm{cal} / \mathrm{mol}$ であ る故, $3 \mathrm{CaO} . \mathrm{SiO}_{2}$ は $\beta-2 \mathrm{CaO} . \mathrm{SiO}_{2}$ と $\mathrm{CaO}$ の和上り $\mathrm{lcal} / \mathrm{mol}$ 即方 $4.6 \mathrm{cal} / \mathrm{g}$ だけ多くのエネルギーを持つ てみる。しかし此の美は小さく, 其の理由として二つ る。（1，2 $2 \mathrm{CaO} . \mathrm{SiO}_{2}$ の水和生成物之 $3 \mathrm{CaO} . \mathrm{SiO}^{2}$ の水和生成物とは違s。(口)，今 $16.7-15.64=1 \mathrm{cal} / \mathrm{mol}$ を堔るとすれば, $1300^{\circ} \mathrm{C}$ に於ける $3 \mathrm{CaO}, \mathrm{SiO}_{2}$ の生
成の際の實熱量は此の值と前表の值より $3.1 \mathrm{cal} / \mathrm{g}$ とな る。（1）と（2）に於て，4.6-2.1=2.5cal $/ \mathrm{g}$ は $3 \mathrm{CaO}$. $\mathrm{SiO}_{2}$ の水和生成が $2 \mathrm{CaO} . \mathrm{SiO}_{2}$ 乙 $\mathrm{CaO}$ の水和生成物 よりも $2.5 \mathrm{cal} / \mathrm{g}$ だけ生成熱が大と言ふ事になる。

$\beta-2 \mathrm{CaO} . \mathrm{SiO}_{2}$ と $\mathrm{CaO}$ より $3 \mathrm{CaO} . \mathrm{SiO}_{2}$ を生成する 時の生成熱が吸熱なればタンマンの內部篹力の減少に より生成物の此重は減少しなければならぬ。事實, デ イカーホフの測定に依れば $3 \mathrm{CaO} . \mathrm{SiO}_{2}$ の比重は 3.25 . であり, $\beta-2 \mathrm{CaO} . \mathrm{SiO}_{2}$ は $3.28, \mathrm{CaO}$, は 3.31 である. 故に $3 \mathrm{CaO} . \mathrm{SiO}_{2}$ の生成熱估是等の 3 方法より吸熱と 認められる。 村上

回韩熹に於てポルトランドセメントと鐵を同 時に製造する方法 (P. P. Collado. Ton. Ind. Ze it., 1936, 60, 123)

回轉筀を用ひる製鐵法はクルップの製鐵法と言はれ。

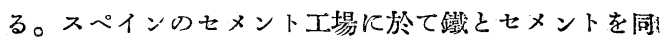
時工業的に製造する方法が研究された。

原料㹥鑛石，石庆石々還元劑としての石炭であつて 之を粉碎混合する。燒成㝘は長さ 45 米, 直徑 2.80米 である。窒の最高溫度は $1500^{\circ} \mathrm{C}$ に昇り, 還元された 鐵は熔けて流出し, クリンカーは $1100^{\circ} \mathrm{C}$ に溫度を落 して新しい然燒空氣に賞り酸化された後クーラーにス る。かくして製造されたセメントはスペインのセメン ト規格に合格する。性質は次の通りである。

細度 4900 目箒殘渣 $7.2 \%, 900$ 目節殘渣 $0.8 \%$

凝始 2 時間 15 分, 凝終 6 時間 15 分

安定度 ルシャテリー安定度試驗機汅より, 沸煮試驗 にて針の開き $\mathrm{Imm}$

24時間 3 日 5 日 7 日 28 日

抗張强度 $\left(\mathrm{kg} / \mathrm{cm}^{2}\right) \quad \begin{array}{llllll}14.4 & 19.5 & 22.2 & 22.5 & 32.5\end{array}$

酎壓强度 $\left(\mathrm{kg} / \mathrm{cm}^{2}\right) \quad 120 \quad 210 \quad 230 \quad 240 \quad 360$ 村上

\section{鹽類湟洫がセメントの初期强度に及ぼす影}

樂 (Grün, Zement, 1936, $25[1], 1-6)$

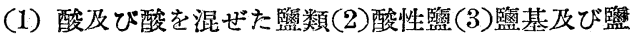

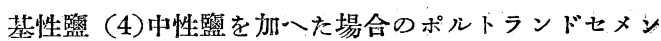
ト及び高爐セメントの $48 \mathrm{hr}$ 以內の强度を試驗した。 籚酸を加一た場合は水練りの場合よりも强くなるが硫 酸及び醋酸は弱くなる。 $\mathrm{NH}_{4} \mathrm{Cl}, \mathrm{CaCl}_{2}+\mathrm{AlCl}_{3}, \mathrm{CaCl}_{2}$ $+\mathrm{FeCl}_{3}$ 何れも强くなるが $\mathrm{Al}_{2}\left(\mathrm{SO}_{4}\right)_{3}$ は $16 \mathrm{hr}$ 以後 は弱くなる。 $\mathrm{KOH}$ は最初は稍强いが， $48 \mathrm{hr}$ 以後は逆 になる。 $\mathrm{K}_{2} \mathrm{CO}_{3}$ 及び $\mathrm{Na}_{2} \mathrm{SiO}_{3}$ は何孔も弱くなる。 $\mathrm{CaCl}_{2}$ は强度の促進最著しく其の $24 \mathrm{hr}$ 强度はアル ミナセメントを淩駕する。 
特殊セメントに就て（R. Grün, Angew, Chem, $49[4], 85 \sim 95)$

堰堤工事等に使用される特殊セメント單味セメント 及び混合セメントに分類し各種セメントに就き其の發 熱, 强度, 透水性, 炭酸及び硫酸監に對する抵抗性を 論じたすのである。

\section{道路用セメントの强度測定用䙲練モルタル梁} 形試驗片の成形及試䛗(Otto Graf, Zement, 1936, 25 [7]97〜103)

試驗の誤美を少くし冬試驗所の成績を一致せしめる 管めに行つたもので型は $4 \times 4 \times 16 \mathrm{~cm}$ を突棒は重量 $0.7 \mathrm{~kg}$, 下面 $15 \times 2 \mathrm{~cm}$ を用ふ。水セメント比は 0.6 に 一定し軟度は小形フローを用ふ。型詰方法として從來 の $310 \mathrm{~g}$ 宛 2 回に詰める方法は其の分量が型の容積

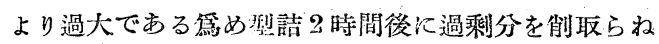
ばならぬ從つて其の際表面に浮いて居る混和水の過剩 分をも捨てねばならず供試體は過分に密實になる。著 者は寧る $285 \mathrm{~g}$ を 2 回に填める方を推獎して居る。 この量ならば㤠の容積を超すととなく型詰後㨁ちに表 陌を均して扎けば水の流去ること無く操作も簡單であ る。每畨の厚さ中文詰方郎突棒によるか又はフローテ ーブルに載せて摇り达む等柱結果に大した影響なしな い、水中荃生の試驗結果はよく一致するが聯結養生は 差が多い。これは試驗室の氣象狀態によるものである から此の場合に注溫度滋度等の協定が必琶である。耐 壓試驗は抗折試驗破片を用ひ從來 $4 \times 14 \mathrm{~cm}$ の受厴面 で武驗されて居るが既設の設倩を利用する意味から受 眮面を大きく $4 \times 6.25=25 \mathrm{~cm}^{2}$ にして見た。 $7 \times 7 \mathrm{~cm}$ の立方形型に比較すると $4 \times 4 \mathrm{~cm}$ 型は $0.8 \sim 1.1,4 \times$ $6.25 \mathrm{~cm}$ 型は 1.1〜1.3 倍の喃壓力となる。同一試驗片 に於ては人誤差は僅少である。同一人が時を經て同一 試料を試驗した場合水中硬化のは哭差少いが聯結硬化 のは誤差が大きい，これは前に記した通りである。

古薮

\section{特殊ポルトランドセタントの研究(第 5 報) 大} 型輦練モルタル《よるマンガンクロムセぬント

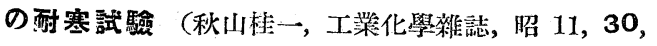
[3], 203 206)

天然原料より工場に於て包轉筌により大規模に整造 せられた特殊セメント及び普通セメントを同一佟件に 於て低溫品深試驗を行つた, 即ち大犁軟練モルタルに まり $3 \sim 6^{\circ} \mathrm{C}$ の寒冷椟氧中硬化及び-1 $2^{\circ} \mathrm{C}$ の水水中 硬化試驗を行つた結果マンガンクロムポルトランドセ メントは前通つポルトランドセメントに比し優秀な耐
寒硬化强度を發揮することを明かにした。此の事は今 後の寒中工事酷寒地の施工等に重要視せらるべきもの であらら。

\section{古 薮}

\section{ポルトランドセメントの强度に及ばす無㙨監}

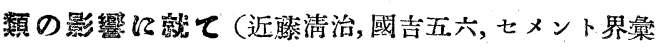
辩, 昭 11,[3],168〜178)

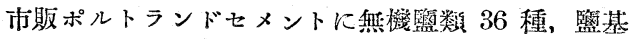
2 種, 酸化物 1 種有機物 1 種を 0.5 ～ $3 \%$ 添加し $1: 3$ 規格モルタルの抗張力を試驗した。其の結果より硬化 促進の見込むる篮類の內 $\mathrm{CaCl}_{2}, \mathrm{Ca}\left(\mathrm{NO}_{3}\right)_{2}, \mathrm{MgBr}_{2}, \mathrm{Cu}$ $\mathrm{SO}_{4}, \mathrm{NiCl}_{2}, \mathrm{MnSO}_{4}, \mathrm{~Pb}\left(\mathrm{NO}_{3}\right)_{2}, \mathrm{CO}\left(\mathrm{NH}_{3}\right)_{4} \mathrm{SO}_{4}, \mathrm{NH}_{4}$ $\mathrm{NO}_{3}$ の 9 種学撰び $3,7,28, \omega$ 强度を测定した。監類 の作用は陽イオン及び除イオンの種類によつて變るが

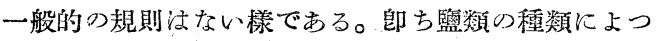
て變るとしか言入ない。然しアルカリ食屬は明らかた

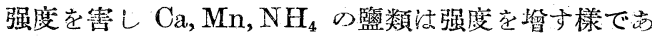

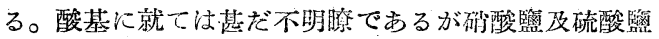
中に强度を筜進したものが比較的多かつた。 $\mathrm{Ca}\left(\mathrm{NO}_{3}\right)_{2}$, $\mathrm{CuSO}_{4}, \mathrm{MnSO}_{4}, \mathrm{Co}\left(\mathrm{NH}_{3}\right)_{4} \mathrm{SO}_{4}$ 及び $\mathrm{NH}_{4} \mathrm{NO}_{3}$ は著し く硬化を促進した。古慜

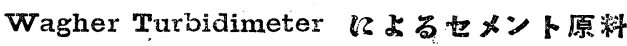
の比表面積の測定 (T. Asano, Rock Prod., 1936, 36 [2], 34 -37)

Wagner Turbidimeter はセメントの比表面積及㯝 子分布の逃速測定償用されるが之をセメント原料に 使用するに就ては七メントの場合には問題とならなか つた種くの疑問が生れる。例一ば原料の比重, 色合の 差造の影響乃至粘土の微粉の如く極微粉に於ては光度 と粒子琵面䅡の一般關係が逆になる事より來る誤差等 を考一ねばなら奴。然し著者の意見によれば此等の未沫 知項に關して何等の補正を行はずとも大部分の原粞: 於ては其㦎枌碎作業の監視儿充分做用出來る。殊飞其 の操作が迅速で古るから 2 工場に於ける・原料粉碎作 業の管理には適當して居る。但し繁濁液の濃度注蒸溜 水 1 中 中に原料 $1 \mathrm{~g}$ 以下とせねばなら收。解膠劑とし

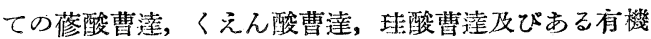
藥品の效果を試驗した結果何孔も水のみの場合よりは 效果はあるが珪酸曹達が最適であつた。セメント原料 の本均此重を 2.60 とする之粒子刀沈降時間を求める

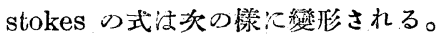

$t=1147000 \mu h / d^{2}$ 茲: $t=$ 沈降時間(秒), $\mu=$ 水の絕啮粘度, $h=$ 光線面迄つ照濁液の深 $\mathrm{cm}$ ), $d=$ 枌子徑 $(\boldsymbol{\mu})$ とま。 


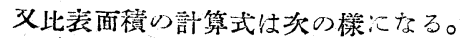

$S=46 r\left(2-\log T_{60}\right) / 1.5+0.75 \log I_{75}+\log I_{10} \cdots \cdot \log$ $I_{55}-11.5 \log I_{60}$

始に $S=$ 比表面䅡 $\left(\mathrm{cm}^{2} / \mathrm{g}\right), \gamma=325$ 委穊上殘渣,

$I_{7.5}, I_{10} \cdots=$ 粒徑 $7.5,10 \mu$ 以上の粒子の沈降した 殘りの眯濁液を透過した光線の强さ(ミクロアンペ ア)とす。

同一試料儿つき此 Turbidimeter と Andreasen ピ ペット法と風箱法とを此較試驗すると一般に 3 者なよ く一致する，唯極く細い試粼氏於て注 Andreasen 法

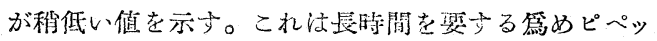
卜内武集凝学起すむのらしい。かくて Turbidimeter 法汢他の法に比べて數分の一の時䦩で完了する點に於 て最名使用儿便でまる。 古 孉

\section{VIII. 雜(砰磨 劑)}

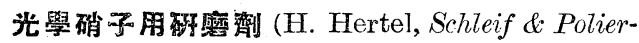

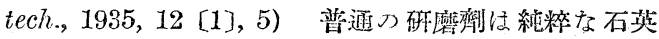

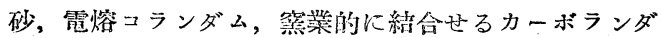
ム，及びダイヤモンドである。天然產圷リーは稀に

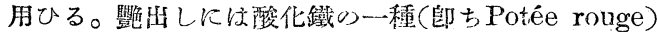
が用ひられる。粘子組成心就て谷㮔の例が與一られて みろ。

冈 田

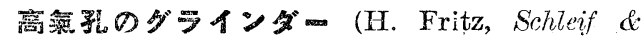
Pctiertech., 1935, 12 [1], 1) 最近に至る远圓板グラ インダーは（1）磔磨劑の性質，(2)粒子つ大さ，(3) 結 合矵つ懏質，及び（4)硬度に依つて特微づけられて居

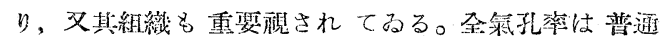
$50 \%$ 以下で各單一の氣孔粒于の大さより小さい。

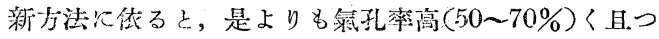
氮㤂が個々の制子より大なる圆板がラインダーの製造

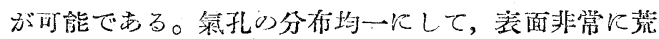

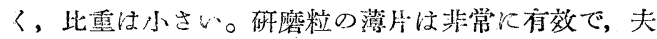
が氮孔中て大り，其庭から遠心力に依って突出され る。又此新法に依れば, 研碅粒心減量㤃生減される。

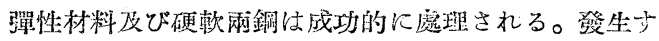
る熱け湆通よりも非常:少なく，均衡が窑易である。 又是等つテーブルは大なる速度にも耐え自働及び牛肖

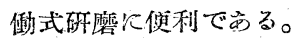

内田

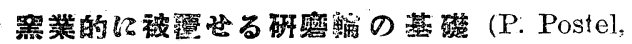
Schleif \& Poliertech., 1935, 12 [5], 94) 研睆輸》

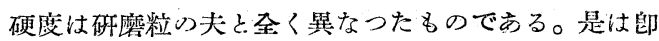
ち個々の粒子を固定する兔の强度を意味するものであ

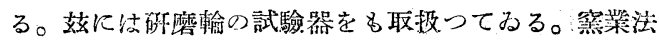

に依る結合劑は多量の熔劑を含育する粘土か，或は維 土に多量の愹劑を加一るもので，粒于をを固定するに足 る釉を加熱し熔融文は牛熔融することに依つて䌡合す る。

内田

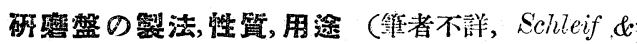

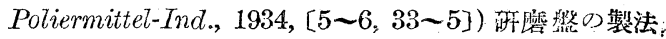
は原料を碎き，適當な粒子几篩別し，適虽なる結合䂰 と混合し, 此混合物を $50 \sim 200 \mathrm{~kg} / \mathrm{cm}^{2}$. の水潜でプレ

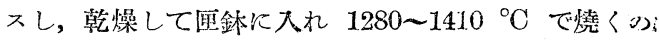

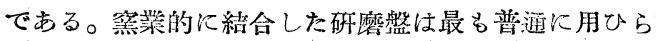
れる。珪酸監の絽合劑を有する圆盤は强度小沉して細 出い仕静にのみ用ひられる。强度大にして肉薄の圆盤 を作らんとせばゴムの結合でする。是け窒業的結合の. 時よりも速い廹轉に耐元るものを作る。シェラック䋹 合に依る時仗より薄く且つ細かい圓盤を作ることが出 來る。人造樹脂も亦結合劑として用ひられる。

內田

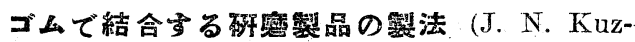
mick \& J. A. Lange, U. S. 1990737, Feb., 1985) 普通のゴム混合法に於て, 磁磨粒の破碎を防 は，ゴムは先づ $\left(\mathrm{C}_{10} \mathrm{H}_{8}\right.$ の如き液化材料を混合して加 熱 $(200$ - 350 $)$ し.て糖蜜に類似した狀態とする。次に

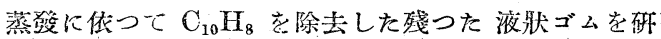

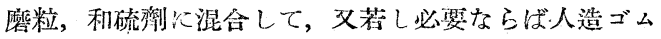
を名混机し，成形して和硫する。

附田

多1ルの一組成 (A. Schneider, U. S. 1670921, Aug. 1934) 此》イルの素地は石英父は大珪石の粉 末 $601 \mathrm{lb}$ ，急硬ポルトランドセメント 401b，力ゼイン $7 \mathrm{OZ}$, 水 7 ガロンのもので, 翰燥後, $2 \%$ メテアリン. 酸石灰 $10 \mathrm{lb}$ 石英又驻大理石心粉利 $21 \mathrm{~b}$ 染料 $2 \mathrm{lb}$, 膠 1 1/4lb, カゼイン 1 1/4lb(少量の $\mathrm{NH}_{4} \mathrm{Cl}$ を含有する. 水 3 ガロン中にとかした)を含有する白色セメントの 泥彇體を以て被㙏するものである。

队时

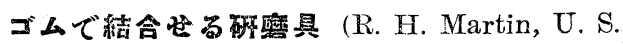
2022893, Dec. 3, 1935) 呼隐輸の如き器具では結晶ア ルミナ又はカーボランダムの如き研磨粒け水に溶けな い弗化物 (例一ば $\mathrm{CaF}_{2}$ ) を含む硬い和硫ゴムで結合す る。 $\mathrm{CaF}_{2}$ は普连の砸磨溫度に於て，ゴムの熱抵抗及 び强度を高めるに洤立つものである。

冈田

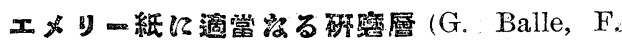
Grom \& K. Wolf, U.S. 2023191, Dec.,3, 1935)研磷 粒はマレイン酸の硬化縮合體， ，又は其無水物とカス ター油とを含有する結合體を以て結合するとよい。

内田 
防火及び斷熱劑としての石綿及び鈸物綿(Von

Faerber, Techn. Blätter zur D. Bergwerks-Ztg. 1935,[43],746７）石綿の中で純度高く產出する溫石 線が最も耐火度高く $1500 \sim 1600^{\circ} \mathrm{C}$ の盜度に酎えるも

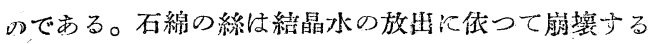
から絲, 織物等の適賞の製作法に依つてのみ製品の原

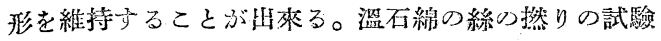
に依ると外見上均一等る絲汇純度大なる，本行に配列 した鐄物片を得し，艋數の氣孔を有する多孔性のもの を作る。此多孔些の組織汉断熱に適するものでする。 厚紙樣のもの乃至固いものにプレスしたるのは眑熱性

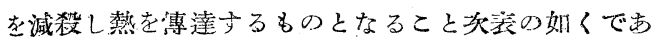

る。

$\begin{array}{lcr} & \text { 容重 }\left(\mathrm{kg} / \mathrm{m}^{3}\right) & \text { 等漙導 } \\ \text { 長繊維石綿 } & 293 & 0.0619 \\ \text { 石 綿 毛 } & 200 & 0.0705 \\ \text { 石 綿 布 } & 575 & 0.0692 \\ \text { 石 綿 紙 } & 930 & 0.1300 \\ \text { 石綿煉正及びモルタル } & 1970 & 0.3500\end{array}$

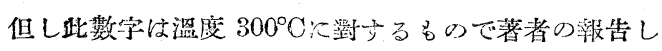

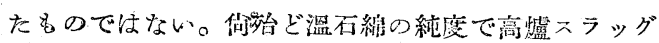

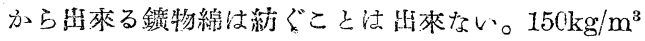

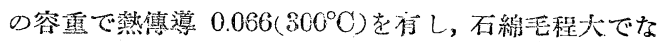
以。

冈田

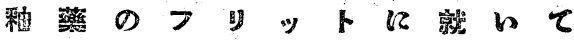

1935 年 11 月 21 日, 在伯林, 『ケラミッセ・ルンドシャウ』所載

$$
\left.\begin{array}{ll}
0,03 \mathrm{MgO} \\
0,03 \mathrm{ZnO} \\
0,94 \mathrm{PbO}
\end{array}\right\} \quad 0,12 \mathrm{Al}_{2} \mathrm{O}_{3}\left\{\begin{array}{l}
1,95 \mathrm{SiO}_{2} \\
0,19 \mathrm{SnO}_{2}
\end{array}\right.
$$

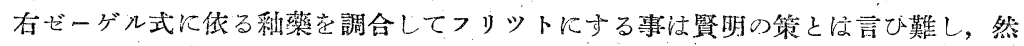
し, 令是をフリットにせん乞する場合には, 適宜に, 乾燥混合して, 坫堝に入れるの であるが，是等全部をフリットにせずしてて，例一ば，後で粉卒機上で，カオリンを添 加せんとする場合は自から別である。さは云一斯かる場合は，カオリンの一部分を共 にフリットにするのが良策だら5, と云ふのは, 然らざる時活, 其フリット注㴽しく 知透を星する恐れがあるからである。

偖て, 其開合珪学舉示すると次の通り,

(1) フリット

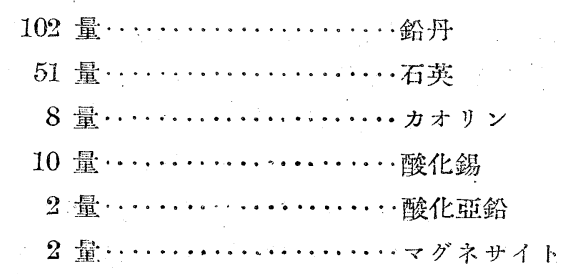

(2) 粉碎物
$1 \mathrm{C00}$ 量……........... リット

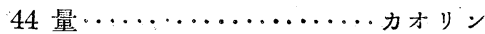

